\title{
Environmental Flows in the Lower Ebro River and Delta: Current Status and Guidelines for a Holistic Approach
}

\author{
Carles Ibáñez ${ }^{\mathbb{D}}$, Nuno Caiola and Oscar Belmar * $\mathbb{D}$ \\ IRTA, Program of Marine and Continental Waters, Sant Carles de la Ràpita, 43540 Catalonia, Spain; \\ carles.ibanez@irta.cat (C.I.); nuno.caiola@irta.cat (N.C.) \\ * Correspondence: oscar.belmar@irta.cat
}

Received: 9 August 2020; Accepted: 22 September 2020; Published: 24 September 2020

\begin{abstract}
Deltas are a particular type of estuarine system in which the dependence on river flow (water, sediments and nutrients) is very strong, especially in river-dominated deltas such as the Mediterranean ones, but environmental flow (e-flow) proposals for deltaic systems are scarce. The Ebro Delta is one of the largest wetland areas in the western Mediterranean and one of the most important estuarine systems in Europe. The aim of this paper is to review the state of the art regarding e-flows and to carry out a critical analysis of the proposals for the lower Ebro River and Delta, in order to highlight the possible environmental and socioeconomic impacts arising from the e-flow regime currently approved. Additionally, based on existing scientific information, methods to establish an e-flow regime that allows the maintenance of the main socio-ecological functions and values are discussed; including those functions and values for which not enough information is available. The study concludes that the currently approved e-flows are not suitable for maintaining most functions and values, as they would not prevent the proliferation of alien fish species and macrophytes in the river, the intrusion of the salt wedge in the estuary, the deficit of sediment/nutrient transport and the degradation of riparian habitats or the decline of coastal fisheries. Socioeconomic consequences on coastal fisheries, river navigation, salt water intrusion, sediment deficit, biodiversity, water quality, aquaculture and hydropower are also considered. Other e-flow proposals such as the proposed by the Catalan government would be more suitable to maintain the main socioecological functions and values of the lower Ebro River and Delta. Nevertheless, additional studies are needed to validate e-flows in some relevant aspects such as the capacity of the river to transport sediments to the delta to avoid coastal regression and mitigate the effects of sea level rise and subsidence, as well as the capacity of floods to control the spread of macrophytes. The lower Ebro River and delta is among the case studies where more quantitative and qualitative criteria to set e-flows with a holistic approach have been established.
\end{abstract}

Keywords: environmental flows; holistic approach; estuary; Ebro River; delta

\section{Introduction}

Numerous studies have shown the effects of modifying the natural hydrological regime on ecosystems [1]. A reduction in flow alters the width, depth, velocity pattern and shear stress [2,3]. Such variations can modify the distribution and availability of in-stream habitat, which can have detrimental effects on invertebrates and fish populations [4] and produce invasion of non-native species (e.g., [5]). In this context, environmental flows (e-flows) are calculated to define the "quantity, timing, and quality of freshwater flows and levels necessary to sustain aquatic ecosystems which, in turn, support human cultures, economies, sustainable livelihoods, and well-being" [6]. 
The science and practice of e-flows constitutes an approach to protect and recover aquatic biodiversity, ecosystem integrity and important ecological services in rivers and estuarine systems. The several methodologies that have been developed are organized in three general categories [7]. First, hydrological methods, which are based on the analysis of historic (existing or simulated) streamflow data and the supposition that such e-flow regimes drive ecological processes in streams and rivers, assuming that most of the species can cope with low flows typical of dry periods (i.e., summer flows or drought periods). Second, habitat simulation methods, which consist of physical or hydraulic modelling of the river channel and, then, modelling the corresponding biological response through different parameters (water depth, flow velocity, substrate composition, etc.). These methods are often used as a "biological validation" of the hydrological ones and are based on a single-species approach. Third, holistic methods to overcome limitations of the previous ones. They are sometimes referred to as "expert panels" where a multi-disciplinary team of experts seeks to consider ecological, social, cultural and economic functions and values of e-flows. Holistic approaches result recommendable for complex environments such as large rivers or estuarine systems, where multitude of factors must be taken into consideration.

Holistic e-flow methods have been developed during the past two decades and can be grouped into two main approaches based on either a bottom-up or top-down procedure to establish e-flow regimes [8]. The bottom-up procedures assume that it is possible to identify and quantify the critical components of the e-flow regime that need to be maintained, while top-down procedures assume that the whole natural flow regime is ecologically important but some flow components can be modified or removed without significantly altering ecological functions and values [9]. The first and best-known holistic approach is the Building Block Method (BBM) that was developed in South-Africa in the early 1990s to establish e-flow standards using limited amounts of data, and is designed to set an e-flow regime to maintain a river in a predetermined condition [10]. This method is based on the identification of the most important components, or "building blocks", of the natural low flows and floods essential for river biota. Unlike BBM, the DRIFT methodology (Downstream Response to Imposed Flow Transformation) is a top-down, interactive, scenario-based approach that includes all major abiotic and biotic components that constitute the ecosystem to be managed [11]. The DRIFT method includes four modules: biophysical, sociological, scenario development and economic. Another holistic method, the benchmarking approach, was designed to link data on alterations of natural flow regimes to ecological consequences; the main idea is to evaluate the condition of a range of rivers (or river reaches) that have been subjected to various degrees of flow regulation and water resource use [12]. Finally, the ELOHA framework (Ecological Limits of Hydrologic Alteration) is a more recent consensus approach from a group of internationally recognized environmental flow scientists to determine ecological limits of flow alteration at a regional scale [13]. For this purpose, rivers are classified according to their hydrological regime in order to define the ecological consequences of anthropogenic alteration within each class. Such framework simplifies the task because it avoids working on a river-by-river basis, but special attention must be paid to the types of rivers used and their suitability to discriminate relevant hydrological characteristics [14]. The main weakness of holistic methods is the assumption that the experts have a comprehensive knowledge of what constitutes a critical flow component for the considered functions and values (see [7] for details of the described holistic methods and their limitations). Moreover, some authors argue that classical approaches are not suited to modified and managed rivers where returning to natural conditions is no longer feasible, and their objective is to design e-flows in order to maximize natural capital and support economic growth, recreation or culture [15].

Estuarine systems are paradigmatic coastal landforms depending on river flows where the link between such flows and their socioecological functions and values is typically complex, so holistic methods are even more necessary for establishing e-flows than in rivers. Deltas are a particular type of estuarine system in which the dependence on river flow (water, sediments, nutrients) is very strong, especially in river-dominated deltas such as the Mediterranean ones [16,17], but e-flow proposals for 
deltaic systems are scarce [18-22]. E-flow requirements of estuaries have been ignored in the past, mostly because of the lack of long-term monitoring data or understanding of the responses to changes in freshwater inflow [23]. Three main countries have developed methods for estuaries (i.e., Australia, South Africa and USA), from practical applications and a learning-by-doing approach [23-28], but some efforts have also been made in other countries like China [22,29]. Recent methods take a holistic and adaptive standpoint and are presented as frameworks that include a number of steps and have elements of risk assessment and adaptive management [23]. Effective e-flows need to be explicit about flow-ecology relationships to adequately determine the amount and timing of water required [30]. This is not an easy task, especially in estuarine systems, so the main challenge is to perform good quality research and monitoring to establish sound quantitative relationships between flow regime features and socioecological functions and values, acknowledging that in many cases it is very difficult and too simplistic looking for single quantitative flow-function/value relationships. In this synthesis paper we use the case of the lower Ebro River and its delta to illustrate the complexity of establishing e-flows in a large river connected to a protected estuarine system, and the need to use a holistic approach in order to consider as many functions and values as possible.

The Ebro Delta is one of the largest wetland areas in the western Mediterranean and one of the most important estuarine zones in Europe [31]. Declared Natural Park in 1983, Special Protection Area (SPA) under the Birds Directive (Directive 2009/147/EC) in 2006 and World Biosphere Reserve in 2013, more than 8000 ha are protected by the Spanish legislation. The delta shows a great diversity of habitats, with endemic faunal (ornithological and ichthyologic) and halophilic floral composition [32], together with important human activities that require flows such as rice agriculture, fisheries, aquaculture and tourism [20]. Consequently, the lower Ebro's hydrology, geomorphology and ecology are strongly impacted by the existence, features and operation of dams [33].

The aim of this paper is to carry out a critical analysis of the e-flow proposals for the lower Ebro River and Delta (Figure 1), in order to highlight the possible environmental and socioeconomic impacts arising from the e-flow regime approved by the PHE. Additionally, based on existing scientific information, guidelines to establish an e-flow regime through a holistic approach that allows the maintenance of the main socio-ecological functions and values are discussed; highlighting those functions and values for which not enough information is available. More specifically, we show an example of determination of e-flows in which existing scientific information can be used (and is partially used by the Governments) to build an e-flow regime by overlapping the river flow needs of different socioecological functions and values. This is a holistic approach in the sense that the main environmental and socioeconomic functions and values are considered and can be progressively integrated into the e-flow regime. From the other hand, we show what goes on in terms of e-flow implementation by the administrations, comparing the e-flow regime in force (Spanish Government) and the e-flow proposed by the Government of Catalonia. We also show other functions and values not considered in these two official proposals that could be considered in the future to advance towards a more holistic e-flow regime. 


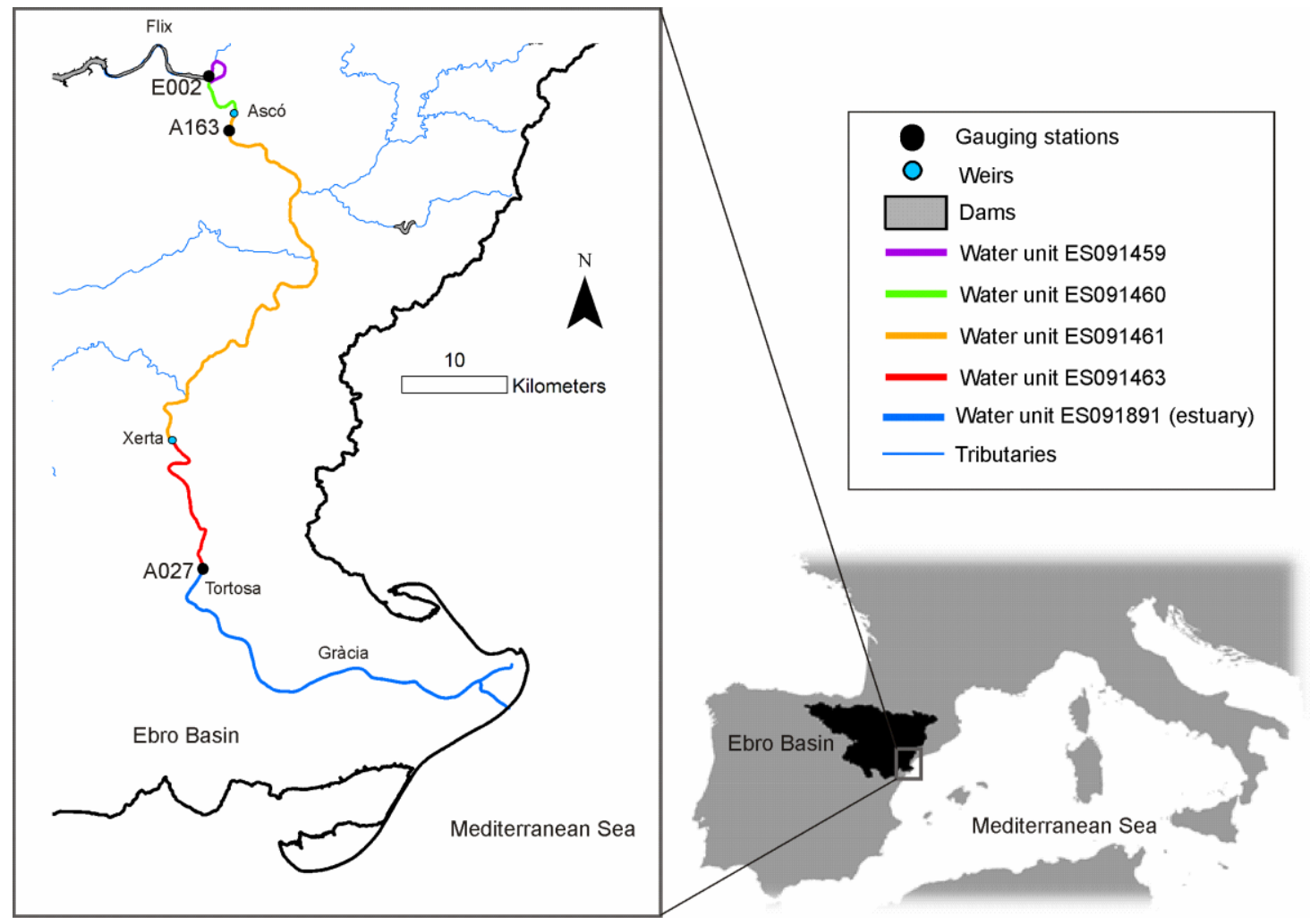

Figure 1. Lower Ebro River and its delta, showing the water units (for hydrological planning) belonging to the river and the estuary. Gauging stations, weirs, dams and tributaries are also represented, as well as the location of the city of Tortosa and the island of Gràcia. Source: modified from Belmar et al. [34].

\section{Requirements and Methods to Establish E-Flows in the Lower Ebro River and Delta}

The European Commission presented in December 2012 the Blueprint to safeguard Europe's water resources, an action plan to protect Europe's water resources. One of the most important points of the Blueprint is the need to develop a guidance document on how to estimate e-flows. In 2015, the European guide "Ecological flows in the implementation of the Water Framework Directive" was published (European Commission, 2015). The guide calls on member states to make the best possible use of available knowledge in relation to e-flows throughout the implementation process of the Water Framework Directive (WFD), but no specific methods are recommended. In accordance with the WFD, the European guide of e-flows [35] considers that their definition must take into account, (a) the principle of non-deterioration of water bodies, (b) the achievement of good ecological status and, (c) the satisfaction of the specific requirements for protected areas designated to protect habitats and species included in the Natura 2000 network where flows are an important factor for their protection.

The legal and technical requirements for the estimation of environmental flows (e-flows) in the Ebro River basin have been evolving over the last 20 years, in accordance with the changes in legislation in the European Union (EU), Spain and Catalonia. The first regulatory framework to establish e-flows in the lower Ebro River was formulated in 1999 and refers specifically to the mouth area, where "a minimum environmental flow of $100 \mathrm{~m}^{3} / \mathrm{s}$ " is set indicatively. Then the Tenth Additional Provision of Law 10/2001, of the National Hydrological Plan (PHN) contemplated the elaboration of the Integral Plan of Protection of the Ebro Delta (PIPDE) with the purpose of "ensuring the maintenance of the special ecological conditions of the Ebro Delta". To achieve this, it was requested to establish a flow regime to allow "the development of the ecological functions of the river, the delta and the nearby marine ecosystem". This specific flow regime for the Ebro Delta has not been established so far, although the Government of Catalonia (through the Catalan Water Agency, ACA) has made several 
proposals to the authority of the river basin (Ebro Hydrographic Confederation, CHE), which have not been accepted.

The creation by the Government of Catalonia of the Commission for the Sustainability of Terres de l'Ebre (CSTE), legally allowed the elaboration of an e-flow proposal for the lower Ebro River and the delta according to the specific requirements of Law 10/2001 of the PHN (modified by Law 11/2005). Terres de l'Ebre is a region that includes the southern counties of Catalonia located in the lower Ebro River basin. Importantly, CSTE integrates all relevant stakeholders and administrations, including the Government of Spain. Studies to formulate the CSTE's e-flow proposal were conducted by the research institute IRTA at request from ACA [36]. The e-flow proposal was finally approved by CSTE in March 2007 and submitted to CHE. The Government of Spain approved in 2007 the "Regulation of Hydrological Planning" and, later, the "Technical Instruction of Hydrological Planning" (IPH; [37]), which develops regulatory contents in relation to the process of establishing e-flows. In summary, such contents establish that e-flows for rivers must be calculated using hydrological methods validated through fish habitat simulation.

Both the European and the Spanish legislations (WFD, PHN and IPH) establish the need to take into account the e-flow requirements to conserve in good ecological status the transitional and coastal waters (estuaries, coastal lagoons, deltas and marine area influence by rivers). The IPH makes specific reference to the environmental functions and values that e-flows must maintain in the case of transitional waters, and therefore to the main environmental impacts that must be avoided. The three fundamental functions are formulated in this way:

(a) That a prolonged duration of the salt wedge in the estuary does not cause conditions of anoxia, nor a significant change or disappearance of species that are not tolerant to salinity, nor an increase in the frequency and intensity of algal blooms, with detrimental effects on the balance of organisms present in the water body.

(b) That sufficient flows are provided to generate nutrient export rates that maintain the productivity of transitional and coastal waters.

(c) That floods are designed to provide the sediments necessary to maintain the characteristic geomorphological elements (river islands, coastal bars, deltas, etc.) and to contribute positively to the coastal dynamics, as well as to the maintenance of the frequency of washing of accumulated sediments and organic matter.

The IPH states that "to the extent that the protected areas of the Natura 2000 network and the wetlands of the Ramsar Convention may be appreciably affected by e-flow regimes, they must maintain or restore a favorable conservation status of habitats or species, responding to their ecological requirements and maintaining in the long term the ecological functions on which they depend".

In this context, the CSTE took into consideration the following main environmental functions and values in its e-flow proposal, both in 2007 and in 2015, in accordance with the legislation in force:

1. Maintaining habitat diversity and their connectivity (including salinity gradients), to avoid substantial changes in the distribution and presence of flora and fauna.

2. Maintaining appropriate hydrodynamic conditions in order to: (a) ensure the frequency and duration of stratification processes, minimizing the risk of loss of bottom water quality due to anoxia or algal blooms; (b) favor the mechanisms of dispersal of certain species (suspension or transport of eggs and larvae, seeds, etc.); (c) control marine intrusion into adjacent coastal aquifers.

3. Maintaining the spatial and temporal diversity of habitat conditions to meet the needs of different species throughout their life cycles.

4. Synchronizing the seasonal patterns of flow and salinity with other environmental parameters (temperature, light, nutrients, etc.) for the maintenance of certain biological processes (reproduction, migration and dispersal, etc.). 
5. Controlling the presence and abundance of the different species of phytoplankton, macrophytes, benthic fauna and fishes, through the control of high flows, to avoid abrasion, erosion and drag in the case of the river and the estuary.

6. Maintaining the physic-chemical conditions of water and sediment in order to: (a) avoid the excessive accumulation of organic matter and anoxia in the river and estuary; (b) favor dilution of point or diffuse pollutants; (c) hinder the conditions conducive to algal blooms; (d) maintain the levels of turbidity that control the light regime in the water column and the primary production of the ecosystems.

7. Improving habitat conditions and availability through geomorphological dynamics in order to: (a) avoid the problems of accumulation of fine particles in the substrate; (b) maintain the distribution of sediment granulometry and mobility; (c) preserve the characteristics of the river channel and its structural elements (river islands, abandoned meanders, etc.); (d) favor the arrival and transport of sediments and nutrients in the estuary, delta and coastal system.

8. Controlling of the hydrological processes that regulate the connection of the transitional waters with the river, the sea and the associated aquifers in order to: (a) control the water flows in the estuary, lagoons and bays; (b) control the frequency, duration and length of the salt wedge; (c) avoid sediment accumulation hindering aquifer-river connectivity.

It should be noted that often there is little information to quantify the effects of flow regime alteration on environmental and socioeconomic functions and values. Further studies are necessary to establish quantitative relationships between flow regime and socioecological functions and values.

In 2015, the CSTE created a technical commission to update the 2007 e-flow proposal, so that the Government of Catalonia could present a new proposal for the next cycle of hydrological planning (Hydrological Plan of the Ebro, PHE). However, the PHE in force (2015-2021) was approved by the Government of Spain without accepting the allegations presented by the Government of Catalonia in relation to the proposed e-flow regime. Thus, the present e-flow regime is very similar to the previous ones, maintaining the indicative $100 \mathrm{~m}^{3} / \mathrm{s}$ established for the mouth area, and is considered to be insufficient by many experts to maintain fundamental ecological and socioeconomic functions and values of the lower Ebro River and Delta [20,31]. For the update of the proposal of ecological flows in the lower Ebro River and Delta [19], the following aspects were considered:

- The new regulatory requirements: especially those established in the "Technical Instruction for Hydrological Planning" (IPH; [37]). The methodology for defining the e-flow regime was also adjusted to follow the e-flow European guide published in 2015.

- The selection of the hydrological method: a review of the main hydrological methods for calculating e-flows was carried out, selecting the one that best suits the conditions of the lower Ebro River.

- The time period of the hydrological series: the same series used in the PHCE were selected.

- The simulation model of the natural flow regime: the same simulation method that the CHE was used.

Such aspects were implemented through a protocol for establishing the e-flow regime proposal, as follows:

- An initial proposal was made based on hydrological methods.

- Subsequently, a biological validation of the hydrological proposal was performed (as indicated in the IPH).

- In addition, further requirements of the Ebro estuary to maintain its functionality and "good condition," as established by the IPH were considered.

- The ecological functions of the river, delta and nearby marine ecosystem have also been considered, as required by the tenth additional provision of the PHN Act.

- Finally, the requirements for protected areas dependent on river flow were also considered, as required by Article 4.1.c of the WFD. 
These aspects were considered combining the biological validation of the hydrological proposal developed, as stated, with an assessment of the ecological characteristics of the Delta. Then, bibliographical research guided the diagnosis of the flow requirements to maintain such characteristics. Additionally, available biological data allowed determining empirical relationships between flows and ecological properties (e.g., alien species). This provided a more holistic perspective.

\section{Current and Proposed E-Flow Regimes in the Lower Ebro River}

This section presents the data of the e-flow regime for the lower Ebro River and delta approved by the Government of Spain through the Hydrological Plan of the Ebro [38] and makes a comparison with the proposal elaborated by the Government of Catalonia [19]. The e-flow regime approved by the PHE implies an annual runoff of $3010 \mathrm{hm}^{3} /$ year that is $17 \%$ with respect to the natural regime in the first half of the last century $\left(17,300 \mathrm{hm}^{3} /\right.$ year), and $34 \%$ with respect to the actual flow regime of the last 20 years $\left(8826 \mathrm{hm}^{3} /\right.$ year). This means that the current runoff in the lower Ebro River is half $(51 \%)$ the original runoff before dam construction, intensive water use and climate change. Notice that the e-flow regime in force is much lower than the current river flow, while the e-flow proposed by the Government of Catalonia ( $7732 \mathrm{hm}^{3} /$ year) is close to the current river flow (see Table 1).

Table 1. E-flow proposals (monthly mean annual flow, $\mathrm{m}^{3} / \mathrm{s}$; total, $\mathrm{hm}^{3} /$ year) for the lower Ebro River and delta elaborated by the Spanish (PHE) and Catalan (CSTE) Governments. The PHE is the proposal presently in force.

\begin{tabular}{cccccc}
\hline \multirow{2}{*}{ Month } & PHE & \multicolumn{5}{c}{ CSTE } \\
\cline { 3 - 6 } & & Dry & Average & Humid & Minimum ** \\
\hline October & 80 & 84 & 124 & 192 & 82 \\
November & 80 & 153 & 219 & 326 & 114 \\
December & 91 & 204 & 249 & 396 & 119 \\
January & 95 & 143 & 219 & 321 & 123 \\
February & 150 & 166 & 260 & 316 & 124 \\
March & 150 & 212 & 283 & 410 & 111 \\
April & 91 & $329 *$ & 410 & 475 & 157 \\
May & 91 & 303 & 410 & 413 & 135 \\
June & 91 & 268 & 310 & 368 & 97 \\
July & 80 & 147 & 180 & 212 & 101 \\
August & 80 & 107 & 132 & 166 & 91 \\
September & 80 & 120 & 151 & 178 & 86 \\
\hline Total & 3010 & 5871 & 7732 & 9907 & 3518
\end{tabular}

* A minimum of 15 days with more than $410 \mathrm{~m}^{3} / \mathrm{s}$ must be guaranteed. ${ }^{* *}$ It corresponds to the concept of exceptionality (severe drought) of article 4.6 of the WFD.

This e-flow regime is very similar to that in force in previous river basin plans (PHE), with a mean annual flow close to $100 \mathrm{~m}^{3} / \mathrm{s}$. The monthly flow distribution of the e-flow regime in force (PHE) and the regime proposed by the Government of Catalonia are shown in Table 1, ranging from 80 to $150 \mathrm{~m}^{3} / \mathrm{s}$ in the first case and from 124 to $410 \mathrm{~m}^{3} / \mathrm{s}$ in the second case (for average years). The last proposal of e-flow regime elaborated by the Government of Catalonia [19] supposes an annual runoff of $5871 \mathrm{hm}^{3}$ in dry years, $7732 \mathrm{hm}^{3}$ in average years, and $9907 \mathrm{hm}^{3}$ in humid years. This e-flow regime corresponds to the Ebro River gauging station in Tortosa (before entering the delta). In order to maintain the hydromorphological conditions of the Ebro River and allow the transport of sediments to the delta, the CSTE proposal also includes a flood regime of an average duration of 27 days during the months of March, April and May. The maximum flow is defined at around $1800 \mathrm{~m}^{3} / \mathrm{s}$ and would be applicable in wet years (and in average years if there are sufficient reserves in the reservoirs). These controlled floods overlap with the e-flow regime, so that they represent an additional runoff of $1548 \mathrm{hm}^{3}$ (out of $2615 \mathrm{hm}^{3}$ flood runoff). The CSTE proposal also establishes a minimum annual runoff of $3518 \mathrm{hm}^{3}$ as the minimum flow in exceptional drought conditions (Table 1), which is not considered an e-flow, 
but corresponds to the concept of temporary deterioration by exceptionality (prolonged drought) in accordance with Article 4.6 of the WFD. This is a measure of "minimum services" to withstand an exceptional period and to be able to recover the good ecological status of the water bodies. In addition to the e-flows, there are irrigation concessions in the delta $\left(370 \mathrm{hm}^{3} /\right.$ year), some of which (30\%) end up in the lagoons of the delta or in the sea (agricultural drainage).

Table 1 shows that the e-flows in force (PHE) are well below the ones proposed by the CSTE, and even below the minimum flow regime of exceptionality (prolonged drought). This implies that, in the event that the planned uses in the basin increase according to water resources allocations granted in the PHE (especially for irrigation), the impacts of the subsequent flow decrease will be progressively higher in the lower Ebro River and Delta, harming both environmental and socioeconomic functions and values [31].

\section{Socioecological Functions and Values to Be Considered for the Quantification of the E-Flow Regime in the Lower Ebro River and Delta}

Here we carry out the analysis of the potential impacts of the e-flow regime in force (PHE) on the lower Ebro River and delta, as well as the flow requirements that would be necessary for those functions and values for which rigorous and quantifiable technical and scientific information is available. The main functions and values for which a quantitative scientific assessment has been made in relation to a holistic determination of the e-flow regime for the lower Ebro River and Delta are summarized in Table 2. The existing scientific and technical information relating flows and socioecological functions and values is analyzed in the next sub-sections.

Table 2. Relationship between river flows and environmental functions and values that have been quantitatively assessed in the lower Ebro River and delta. Compliance with e-flow proposals is shown.

\begin{tabular}{|c|c|c|c|c|}
\hline \multirow{2}{*}{ Functions \& Values } & \multirow{2}{*}{ E-Flow Requirements } & \multirow{2}{*}{ Source } & \multicolumn{2}{|c|}{ Compliance? } \\
\hline & & & CSTE & PHE \\
\hline $\begin{array}{l}\text { Species of conservation concern } \\
\text { (Twaite shad) }\end{array}$ & $\begin{array}{l}50 \% \text { of weighed usable area (WUA) for } \\
\text { breeding is achieved with a mean spring } \\
\text { flow of } 252 \mathrm{~m}^{3} / \mathrm{s}\end{array}$ & IRTA [36] & yes & no \\
\hline $\begin{array}{l}\text { Control of alien species (fish) in } \\
\text { the river }\end{array}$ & $\begin{array}{c}50 \% \text { of weighed usable area (WUA) for } \\
\text { dominance of native over alien species is } \\
\text { achieved with a mean annual flow of } \\
194 \mathrm{~m}^{3} / \mathrm{s}\end{array}$ & $\begin{array}{l}\text { Caiola et al. [39] } \\
\text { CSTE [19] }\end{array}$ & yes & no \\
\hline Good ecological status of the river & $\begin{array}{l}\text { A theoretical mean annual flow }>>400 \mathrm{~m}^{3} / \mathrm{s} \\
\text { would be required to achieve a moderate } \\
\text { ecological status (WFD fish indicator) }\end{array}$ & Belmar et al. [34] & no & no \\
\hline $\begin{array}{c}\text { Control of macrophyte spread in } \\
\text { the river }\end{array}$ & $\begin{array}{l}\text { Spring flood during } 27 \text { days }\left(2615 \mathrm{hm}^{3}\right) \\
\text { with a peak flow of } 1800 \mathrm{~m}^{3} / \mathrm{s}\end{array}$ & Ibáñez et al. [40] & Partially $^{1}$ & no \\
\hline $\begin{array}{l}\text { Control of salt wedge in } \\
\text { the estuary }\end{array}$ & $\begin{array}{l}\text { Minimum of } 410 \mathrm{~m}^{3} / \mathrm{s} \text { to wash away salt } \\
\text { wedge in spring and } 130 \mathrm{~m}^{3} / \mathrm{s} \text { to stop it in } \\
\text { Gracias Island ( } 18 \mathrm{~km} \text { from river mouth) }\end{array}$ & $\begin{array}{l}\text { Sierra et al. [42] } \\
\text { Ibáñez et al. [43] }\end{array}$ & Yes & no \\
\hline Coastal fisheries & $\begin{array}{l}1 \mathrm{~m}^{3} / \mathrm{s} \text { of river flow during the anchovy } \\
\text { breeding period represents an increase of } \\
0.114 \mathrm{Mt} \text { of monthly catch a year later }\end{array}$ & Salat et al. [44] & n.a. ${ }^{3}$ & n.a. ${ }^{3}$ \\
\hline
\end{tabular}

${ }^{1}$ The flood may prevent further macrophyte spread but not remove the current spread. ${ }^{2}$ Further research is needed to quantify more precisely the transport capacity under present conditions in case sediment are by-passed trough reservoirs. ${ }^{3}$ The relationship between river flow and anchovy production cannot be converted into an e-flow requirement. The question "what is the minimum anchovy landing" is meaningless.

In order to better understand the ecological impacts of human intervention on the lower Ebro River in the last decades and help to interpret the complex links between flow regulation and ecological processes we present a conceptual model (Figure 2). This model shows the main impacts of dam construction and the increase in water use that lead to reduced flow, sediment deficit and eutrophication. 
The last 20 years are characterized by a re-oligotrophication due to phosphorus decline as consequence of the implementation of waste water treatment plants and other measure to improve water quality in the Ebro River watershed (see Ibáñez \& Peñuelas [45]).

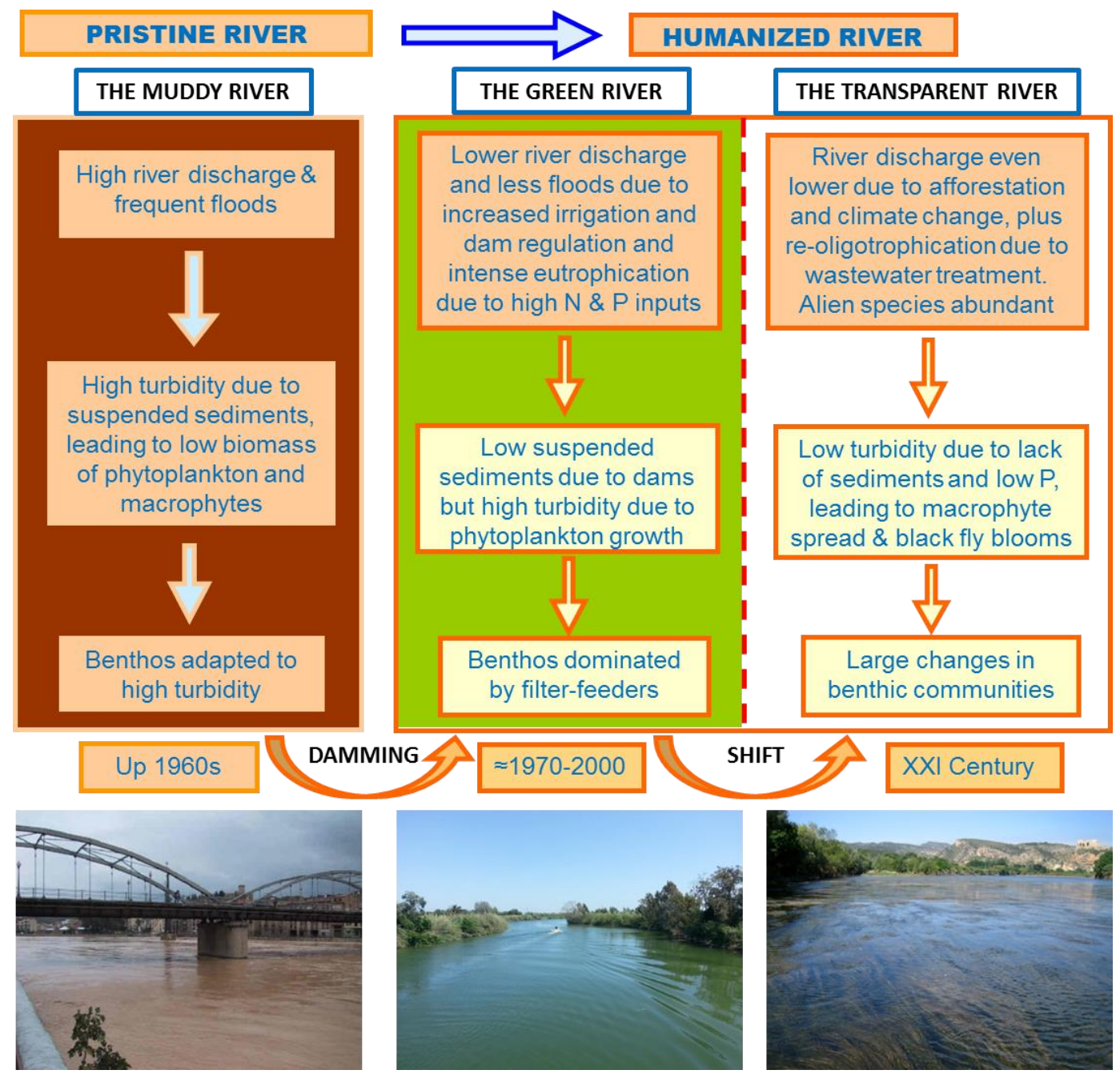

Figure 2. Conceptual model showing the main human impacts and changes in the ecosystem that the lower Ebro River has suffered in the last 60 years.

\subsection{Conservation of Protected Species, Habitats and Ecological Quality}

Until recently, efforts to quantify the relationship between the flow regime and protected species have focused on the case of the Twaite shad (Alosa fallax). This fish species disappeared completely from the river decades ago but has started to recover during the last 20 years. The amount of the Twaite shad reproductive habitat was simulated under different river discharge scenarios in order to determine its relationship with the flow regime [36]. According to this empirical function obtained with field data, a flow of $100 \mathrm{~m}^{3} / \mathrm{s}$ (mean e-flow in force) provides only $20 \%$ of the potential weighted usable habitat (WUA), while $60 \%$ (required by IPH regulations) is achieved with a flow of $252 \mathrm{~m}^{3} / \mathrm{s}$. The e-flows of the CSTE proposal provide potential habitat for Twaite shad in the range of 50-80\% of the maximum WUA as required by the IPH. The available information shows that the e-flow in force (PHCE) violates the Spanish regulations (IPH) and does not guarantee the reproduction of this species.

With regard to the species listed in Annex IV (a) of the Habitats Directive 92/43/EEC, as well as the species included in the Catalogue of Threatened Species of Spain, the e-flow regime should ensure adequate conditions to safeguard the ecological functionality of its breeding and resting areas. 
The available information and the difficulty to link flow regimes with impacts on specific habitats and species, only allows us to make a qualitative estimate of the impact that the e-flow regime in force may have on the protected areas of the lower Ebro and Delta. The habitats and species of the banks and islands of the Ebro would certainly be affected, as the permanent low flows and the suppression of floods would modify the structure of riparian vegetation and cause its degradation [46,47]. The habitats and species of the Ebro Delta would be affected differently with more or less intensity depending on their characteristics; in general, the habitats and species most dependent on the water supply of the river would be the most affected, especially the estuary and some coastal lagoons and wetlands (Garxal, Buda Island, etc.). Finally, the species in the marine area of influence would be affected by the lower supply of fresh water and nutrients, which would have a negative impact on fish production (see Section 4.6) and seabirds that feed on this production. However, additional studies are needed to better quantify these impacts.

Ensuring sufficient river flows is one of the most important management tools to maintain the conservation status of the Natura 2000 sites. The lower Ebro River and Delta region has more than one million hectares of Natura 2000 surface area (125,000 ha of terrestrial sites, 53,500 ha of coastal sites and 901,000 ha of marine sites) The EU Natura 2000 network includes Special Areas of Conservation (SACs) and Special Protection Areas for Birds (SPAs). In such cases, e-flows should be appropriate to maintain or restore the favorable conservation status of the natural habitats and wild species of fauna and flora of Community interest listed in the Annexes of Directive 92/43/EEC and Directive 2009/147/EC. The three protected areas most affected by river flows are "River banks and Ebro Islands" ZEC, the "Ebro Delta" ZEC and SPA and the "Delta-Columbrets" marine SPA. However, the available information for the Ebro River and Delta is not sufficient to establish quantitative flow criteria, so specific studies are needed to deepen into the relationship between flows and conservation status of habitats in order to carry out the biological validation of the e-flow regime.

Some studies in the Ebro have recently been carried out to evaluated the relationship between the flow regime of the river and some components of biodiversity such as the abundance of protected species of birds in the delta, as well as the ecological quality of the final stretch of the river, measured through fish community [34,48]. Such studies showed that flow regime was significantly related to only a few deltaic bird species, and likely due to an indirect effect on prey availability in rainy years. However, a clearer effect of flow regime on ecological quality (EQ) according to the WFD (measured through fish community) was observed in the lower Ebro River. Mean flow magnitude was directly related to EQ and there were two outcomes relevant for water management. First, the effect on EQ was circumscribed to a specific temporal frame matching the annual cycle (12 previous months). Second, despite the positive relationship found (higher scores of EQ with higher river flow), it would be unfeasible to achieve a good ecological status in the lower Ebro only with an increase in mean flow. In this context, the control of the proliferation of macrophytes (which favor alien fish species) that may be done maintaining floods, naturally occurring in spring [40], would allow to achieve a certain EQ with lower river flows. In recent decades, macrophytes have spread due to reduction in high flows caused by dam management, together with the increase in water transparency due to phosphorus removal [49]. Nevertheless, these results also indicate that further research to assess ecological quality in rivers with great abundance of invasive species is necessary, as such species may condition the determination of ecohydrological relationships and the definition of e-flows.

\subsection{Control of Invasive Species in the River}

The efforts to quantify the relationship between the flow regime and invasive species have focused on the effects on the ratio between native and alien species, being one of the metrics considered in the elaboration of the ecological status indices of the WFD. Previous works have analyzed the relationship between flows and such ratio using a univariate logistic regression model [39], which was the basis for the biological validation of flows in the CSTE proposal. This was done through the simulation of flow scenarios by applying hydraulic models to test the biological significance of each of the flow 
proposals, by analyzing the proportion of suitable habitat to maintain the structure and integrity of the fish community in the lower Ebro River (ensuring the dominance of native species over non-native species, listed in Caiola et al. [39]).

Taking as a reference the minimum thresholds of 50 or $60 \%$ of the WUA required in the IPH, it can be estimated that a runoff of $6115 \mathrm{hm}^{3} /$ year would provide $50 \%$ and a runoff of $8429 \mathrm{hm}^{3} /$ year would provide $60 \%$ for native species. One can estimate the percentage of WUA that the different proposals for e-flow regimes would represent, using the relationship showed by the Figure 3. The proposed CSTE e-flows, calculated from hydrological methods, always provided a habitat between 49 and 65\% of the WUA and therefore follows the criteria established by the IPH.

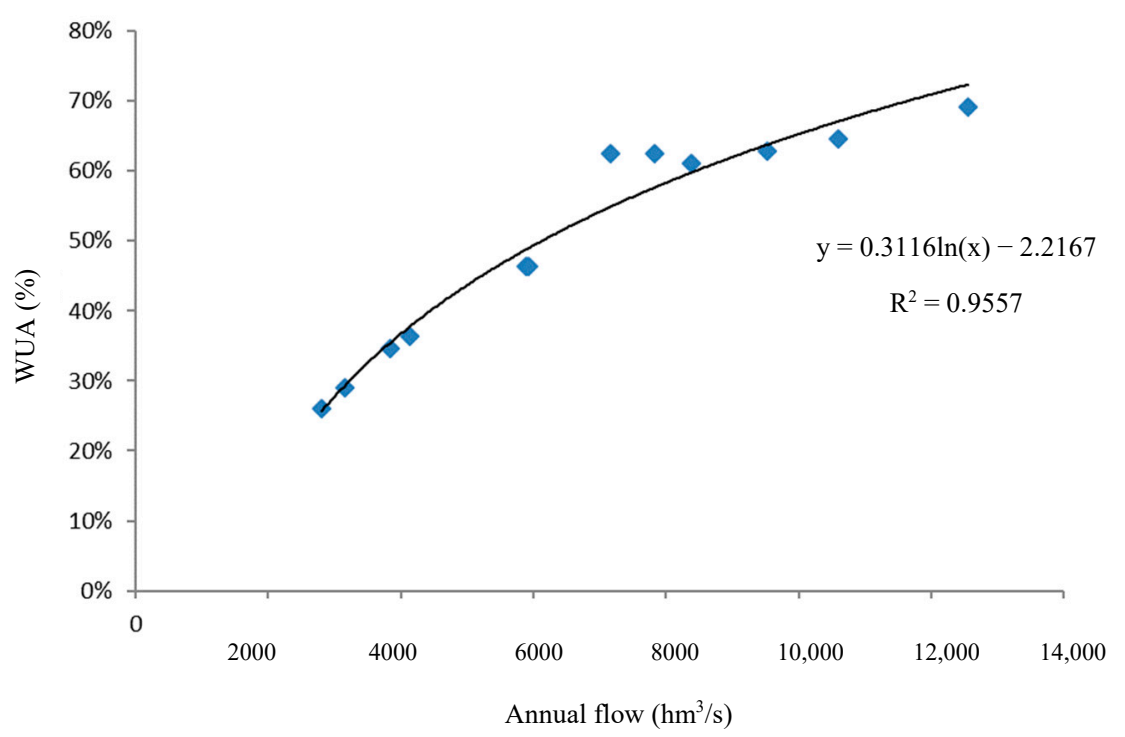

Figure 3. WUA/Flow curve to reach a proportion greater than $50 \%$ between native and non-native fish species in the lower Ebro River. Source: modified from CSTE [19].

The available information also allows us to make an estimate of the impact that the application of the e-flow regime in force (PHCE) would have. In this case, the WUA would be only $28 \%$, well below the minimum of $50 \%$ required by current Spanish regulation (IPH). This would imply a greater proliferation of invasive species and a worsening of the ecological quality index of the WFD based on fish, violating the principle of non-deterioration of water bodies in the European legislation. In any case, despite the adjustment obtained (Figure 3), additional research is necessary to better understand the relationship between flow regimes and the proportion of native species, given the moderate adjustment of the underlying univariate logistic regression model $\left(R^{2}=0.514 ;[39]\right)$.

\subsection{Control of Macrophyte Spread in the River}

Current Spanish regulations (IPH) state that the e-flow regime in the case of rivers must include flood flows, in order to control the presence and abundance of different species, maintain the physical and chemical conditions of the water and of the sediment, and improve the conditions and availability of habitat through the maintenance of the geomorphological dynamics. For this purpose, floods play an important role as disruptive elements that control the presence and abundance of species. Since the commissioning of the reservoirs in the lower Ebro River (1960's), the hydrological regime of the lower Ebro has maintained episodes of floods that have gradually reduced its magnitude and frequency [50]. The environmental monitoring carried out in recent years has allowed establishing threshold values of river flow around $2000 \mathrm{~m}^{3} / \mathrm{s}$ (but significant ecological changes have been observed). For the period 2006-2015, three floods were recorded with a maximum average daily flow equal to or greater than $1800 \mathrm{~m}^{3} / \mathrm{s}$. The average runoff of the three floods was $2724 \mathrm{hm}^{3}$, with an average duration of 27 days, and an average daily flow of $1170 \mathrm{~m}^{3} / \mathrm{s}$ (peak flows were in the range $1800-2100 \mathrm{~m}^{3} / \mathrm{s}$ ). 
In the last 20 years, the proliferation of macrophytes in the lower Ebro River has been great [49] and has had negative effects on the ecological, socioeconomic and hydromorphological system, such as the promotion of invasive species, the proliferation of blackflies, difficulties for navigation and the impact on the cooling system of the Ascó Nuclear Power Plant. The decrease in the floods of the Ebro River due to dam regulation and intensive water use have also led to the deterioration of its hydromorphological status (i.e., riverbed encroachment) and a lower capacity to transport sediments. In 2007, the decrease in macrophyte coverage after a flood could be measured in two sections of about 2 kilometres in Móra d'Ebre and Ginestar [40]. In Móra, the coverage went from 36.6\% to $9.80 \%$, and in Ginestar it went from $21.2 \%$ to $2.0 \%$. The flood of 2015 presented similar flows but a longer duration (33 days). The inspection of the Miravet-Benifallet section by boat showed a very high effectiveness in removing macrophytes, although the change in coverage could not be measured. Further monitoring and research is needed in order to establish the magnitude and frequency of flood to control macrophyte spread.

The available scientific information allows us to estimate the impact that the e-flow regime in force would have on macrophyte proliferation. A regime of sustained low flows and no floods that is characteristic of the present e-flow regime implies a strong proliferation of macrophytes that will tend to be, with a coverage close to $100 \%$ in all areas above $4 \mathrm{~m}$ of depth [40]. This would lead to a whole host of negative effects, especially a much stronger proliferation of blackflies, the proliferation of alien species and a decline of native species such as the protected bivalve Margaritifera auricularia and other protected species.

\subsection{Sediment Transport in the River and Coastal Regression in the Delta}

There is a direct and positive relationship between river flow and sediment transport capacity, but in terms of delta growth (and retreat) sand is the critical material, while fine sediment (silt, clay) is either exported offshore or deposited in the delta plain [51]. However, sediment inputs to deltas has been dramatically reduced in the last decades due to dam construction, being the lower Ebro River an extreme case in which sediment transport has been reduced by $99 \%$ in relation to pre-dam conditions [33]. Annual sediment transport under pristine conditions was in the order of $30 \mathrm{Mt}$ [52], while at present rounds $0.1 \mathrm{Mt}$ [53]. Despite the transport capacity of the lower Ebro River has been significantly reduced after dam construction [50], the river still keeps a remarkable capacity during spring floods (Figure 4). In the lower Ebro River, flows required to transport sand and avoid coastal delta regression must be greater than $620 \mathrm{~m}^{3} / \mathrm{s}$ [54]. The average runoff of spring floods for sediment transport under present conditions has been estimated at $2724 \mathrm{hm}^{3}$, with an average duration of 27 days, an average daily flow of $1170 \mathrm{~m}^{3} / \mathrm{s}$ and a maximum daily flow of $1894 \mathrm{~m}^{3} / \mathrm{s}$ [19]. Based on the characteristics of these floods, both magnitude and duration, it is estimated that they would allow the transport of more than $2 \mathrm{Mt}$ of sediment per year by applying some sediment by-pass system to the Riba-roja reservoir [41], which would substantially slow down the regression of the Ebro Delta coast in the mouth area [55]. It has been estimated that by 2050, considering a sea level rise scenario 4.5 of the IPCC, the annual sediment deficit for the entire delta will be $1.69 \times 10^{6} \mathrm{~m}^{3}$ while by 2100 will be $5.93 \times 10^{6} \mathrm{~m}^{3}$. The minimum deficit to keep the delta above sea level has been estimated at $0.17 \times 10^{6} \mathrm{~m}^{3}$ and $3.30 \times 10^{6} \mathrm{~m}^{3}$ by 2050 and 2100 , respectively [56].

The e-flow regime in force does not allow the generation of these floods, which implies a technical impossibility to bring sediments to the delta, and therefore curb the regression of the coast and the subsidence of the deltaic plain. The available information allows concluding that the e-flow regime in force would accentuate the deficit of sediments and the process of regression of the Ebro Delta, which entails a loss of agricultural land and protected natural areas [57]. An option to face this issue would be the transfer of sediments from the Riba-roja reservoir to the lower Ebro River and delta. Specific studies evaluating the by-pass systems, costs and benefits of the sediment transfer are being carried out, while the practice of sediment by-pass in reservoirs is being progressively expanded all around the world, mostly to avoid the loss of water storage capacity of reservoirs [58]. Moreover, 
further research is needed to quantify more precisely the transport capacity under present conditions in case sediment are by-passed trough reservoirs. The problem relies on the difficulty to calibrate and validate sediment transport models with floods carrying out suspended sediment far below their capacity.

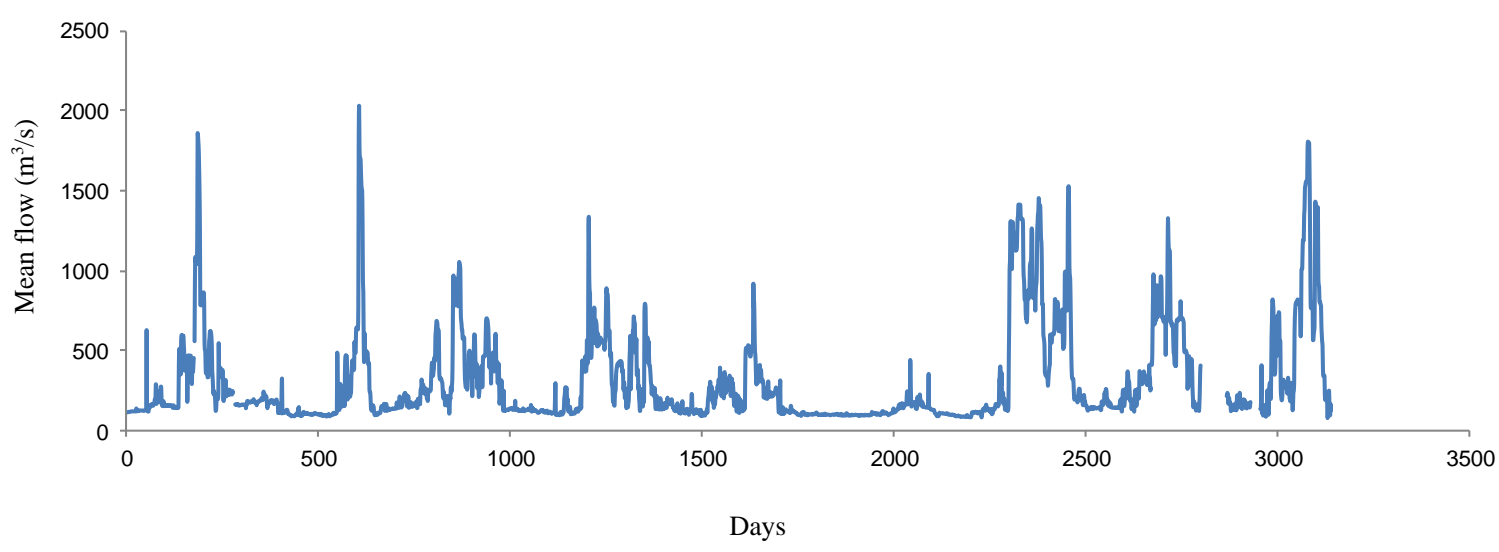

Figure 4. Hydrograph of the lower Ebro River highlighting the main floods for the period 2006-2015. Source: modified from CSTE [19].

\subsection{Control of the Salt Wedge in the Estuary}

The final stretch of the Ebro River (the last $27 \mathrm{~km}$ ) behaves like a highly stratified estuary with a salt wedge. The dynamics of this wedge is important from an ecological and economic point of view and is closely linked to the flow of the river, although there are other factors such as bathymetry and sea level that also play an important role. Several studies have been performed through numerical modelling to evaluate the role of flow regime in the dynamics of the salt wedge $[42,43,59]$. Table 2 summarizes the main results of the studies that have been used in the determination of the e-flow proposal by CSTE, as well as some posterior studies. These studies analyzed the monthly flows under natural conditions based on data from the hydrological model used by CHE, the "Integrated System for Rainfall-Runoff Modelling" (period 1980-2006) and the hydrological series measured at Tortosa gauging station (period 1980-2012). Table 3 compares the flows that, according to different studies, ensure that the river does not have a salt wedge or avoids its pass beyond the island of Gràcia $(18 \mathrm{~km}$ from the mouth), reaching the town of Amposta ( $25 \mathrm{~km}$ from the mouth). Taking the most recent study as a reference [42], the salt wedge is considered to completely disappear with a flow above $410 \mathrm{~m}^{3} / \mathrm{s}$. Based on this requirement, the proposed e-flow regime of the CSTE considered that at least two months a year the flows that wash the salt wedge away are reached (in average years). For wet years, the e-flow is increased to be able to have three months without salt wedge. The aim is to ensure that the presence of salt wedges does not increase significantly with respect to the natural flow regime to avoid hypoxic conditions [43], in order to guarantee the principle of non-deterioration of the ecological status of the estuary.

Table 3. Minimum river flows $\left(\mathrm{m}^{3} / \mathrm{s}\right)$ required for the control of the salt wedge in the Ebro estuary, according to different studies.

\begin{tabular}{ccc}
\hline Study & To Wash Away Salt Wedge & To Stop Salt Wedge at Gràcia Island * \\
\hline Sierra et al. [42] & 410 & 130 \\
Ibáñez et al. [43] & 342 & 120 \\
Guillén \& Palanques [59] & 400 & 150 \\
\hline
\end{tabular}

* Gràcia Island is located $18 \mathrm{~km}$ upstream the river mouth and it constitutes a natural sill to prevent the progression of the salt wedge towards its maximum possible distance ( $32 \mathrm{~km}$ upstream the river mouth). 
The available information allows us to estimate the impact that the application of the e-flow regime in force (PCHE) would have on the salt wedge dynamics. In the event that this flow regime becomes the real regime of the river, the salt wedge would be present in the Ebro estuary permanently, and only two months (February and March) would be downstream the island of Gràcia (18 km from the river mouth). This would imply a worsening of the ecological conditions of the estuary, as the stratification of water favors the accumulation of organic matter and the decrease of dissolved oxygen in the water (hypoxia). As a result, it would violate the principle of non-deterioration of the WFD and other legal norms of Spain and Catalonia.

\subsection{Coastal Fisheries}

Terrestrially enriched river discharge favorably influences biological processes (i.e., growth, survival and recruitment) that affect fisheries production. River effects are most noticeable in oligotrophic seas (e.g., Mississippi River in the Gulf of Mexico, [60]; Rhône River in the Mediterranean, [61]) and in semi-enclosed systems such as the Black Sea [62]. Several studies have shown the influence of river inputs and other environmental factors on coastal fisheries, especially in oligotrophic seas $[34,60,62,63]$. Some of these studies were carried out in the coastal zone influenced by the Ebro River discharge [34,61,63,64]. In these studies, both pelagic fish (European anchovy, Engraulis encrasicolus) and shellfish (caramote prawn, Penaeus kerathurus and mantis shrimp, Squilla mantis) landings showed to be positively influenced by the Ebro River runoff. The life cycle characteristics of small pelagic fish and larvae (high mobility, plankton-based food chain and short life) make them particularly sensitive to environmental variations. The presence of larvae has been strongly associated with freshwater inputs and, in fact, the main spawning areas of anchovies in the western Mediterranean are near the mouths of the two largest rivers in the region, the Rhone and the Ebro. The European anchovy (Engraulis encrasicolus) is distributed throughout the Mediterranean Sea and is one of the main fishing resources, but in the Western Mediterranean, anchovy fishing has shown a declining trend since the 1990s.

An empirical model [44] estimated that an additional contribution of $1 \mathrm{~m}^{3} / \mathrm{s}$ of Ebro River flow during the anchovy breeding period represents an increase of $0.114 \mathrm{Mt}$ of monthly catch a year later. Moreover, $63 \%$ of the variance of the time series of catches is explained by the variance in the flow of the river, with a delay of 12 months (which matches the time span observed in the lower Ebro River, see Belmar et al. [48]).

More recently, Belmar et al. [34] studied the relationship between the outflows of the Ebro River and shellfish species with socioeconomic value such as prawn and mantis shrimp. Like Lloret et al. [44], they found that the temporal scale considered determine the ability of flows or of water quality to explain changes in fish productivity. Nevertheless, such productivity also seemed to depend on the fishing technique. More accurate models would be necessary to improve the relationships found and understand the mechanisms that produce them.

The available information allows us to state that the e-flow regime in force cannot maintain the fisheries of the continental shelf of the Ebro delta. This topic has been studied and partly quantified in the case of anchovies, sardines, prawns and mantis shrimps. However, there will be necessary further scientific studies to determine the quantitative relationship between flows and nutrients of the river Ebro and fisheries production, in order to extend them to other species of high commercial interest where the relationship between flows and fisheries production is more complex.

\subsection{River Flow Regime and Socioeconomic Functions and Values}

The main socio-economic functions and values that are directly or indirectly dependent on the river flows but for which sufficiently contrasted information is not available to make a quantitative assessment of the impacts derived from the altered flow regime are the following (see summary in Table 4): 
- Besides the dependence of coastal fisheries on river flow in terms of maintaining biodiversity and biological productivity, the studied quantitative relationship can be converted into social and economic costs that should be quantified. However, the relationship between river flow and fish landings cannot be converted into an e-flow requirement, as it is the case for many socioeconomic functions and values. Regarding aquaculture, there are evidences that reduced river flows can impact shellfish production (mussels, oysters, etc.; [65]), but no quantification has been done in the delta yet.

- The minimum flow required to guarantee the navigability in the lower Ebro River was set in $120 \mathrm{~m}^{3} / \mathrm{s}$ in the Navigability Project (touristic navigation). The e-flow regime in force only exceeds this figure in February and March, while the rest of the year navigation is partially compromised. CSTE e-flow proposal complies with this flow in average and wet years, but not in dry years. The difficulty to maintain this minimum flow has triggered the elaboration of projects to dam the river in order to increase river depth [66], which has created a lot of controversy due to the potential negative environmental impacts and positive socioeconomic impacts.

- Salt water intrusion through the estuary due to low flow conditions may affect soil salinity and productivity of delta rice fields, as suggested by some studies [67]. Further research is needed to quantify these effects and estimate economic losses.

- River sediment deficit due to retention in reservoirs is causing a severe coastal retreat in the mouth area (Buda Island) and hundreds of hectares of wetlands, coastal lagoons and beaches have disappeared [57]; rice production is also threatened in some areas. Besides the loss of biodiversity and ecosystem services there is a socioeconomic loss that has not been quantified yet. Increasing the downstream flow of sediments retained in upstream dams is a crucial measure for dealing with climate change threats (sea-level rise) in the Delta, but public policies do not increase sediment flow. Instead, they implement incremental adaptation at the impacted site (coast), which implies economic costs (small-scale land expropriations) and causes social conflict [68].

- Besides the direct land loss due to coastal regression, biodiversity (habitats and species) is affected by declining flows in many direct and indirect ways, and there are social and economic values associated to biodiversity loss that should be estimated, though often a monetary quantification is limited or not possible.

- Given that there is a direct (but complex) relationship between water quantity and quality in rivers and estuaries [69-72], the decrease in flows would have a potential negative economic impact on aspects such as drinking water, industry, agricultural production and water treatment.

- Decreased flows may also have direct and indirect impacts on tourism: river navigation, blackfly proliferation, sport fishing, habitat degradation, etc., but they have not been quantified.

- The impacts on industrial activities must also be considered, especially on the hydropower production [73] and cooling needs of the Ascó nuclear power plant, but no quantification has been done yet.

- The social impacts of the loss of heritage should also be analyzed, given that the population of Terres de l'Ebre (lower Ebro basin) has a very strong perception that the Ebro River and Delta have important cultural, economic and symbolic value. 
Table 4. Relationship between river flows and socio-economic functions and values of the lower Ebro River and delta that have been assessed with existing information, mostly qualitative because of the lack of studies.

\begin{tabular}{|c|c|c|c|}
\hline Functions \& Values & E-Flow Requirements & Source & Comments \\
\hline Coastal fisheries & $\begin{array}{c}\text { Several quantitative relationship } \\
\text { between river flow and fisheries of } \\
\text { European anchovy, caramote prawn \& } \\
\text { mantis shrimp }\end{array}$ & $\begin{array}{l}\text { Sant Felíu [64] } \\
\text { Salat et al. [44] } \\
\text { Belmar et al. [34] }\end{array}$ & $\begin{array}{l}\text { The relationship between river flow } \\
\text { and fish landings cannot be converted } \\
\text { into an e-flow requirement, but an } \\
\text { economic loss can be estimated }\end{array}$ \\
\hline River navigation & $\begin{array}{l}\text { The minimum flow for touristic river } \\
\text { navigation was set to } 120 \mathrm{~m}^{3} / \mathrm{s}\end{array}$ & Roset [74] & $\begin{array}{l}\text { The e-flow regime in force only } \\
\text { exceeds this figure in February and } \\
\text { March. CSTE proposal complies with } \\
\text { this flow in average and wet years }\end{array}$ \\
\hline Salt water intrusion in rice fields & $\begin{array}{l}\text { An inverse relationship between river } \\
\text { flow in winter and soil salinity in rice } \\
\text { fields has been found }\end{array}$ & Genua-Olmedo et al. [67] & $\begin{array}{l}\text { The relationship between river flow } \\
\text { and fish landings cannot be converted } \\
\text { into an e-flow requirement, but an } \\
\text { economic loss can be estimated }\end{array}$ \\
\hline $\begin{array}{l}\text { Sediment deficit and coastal } \\
\text { retreat in the delta }\end{array}$ & $\begin{array}{l}\text { Sediment retention in reservoirs is } \\
\text { causing a severe coastal retreat in the } \\
\text { river mouth area (Buda Island) and } \\
\text { socioeconomic impacts }\end{array}$ & $\begin{array}{l}\text { Valdemoro et al. [57] } \\
\text { Zografos [68] }\end{array}$ & $\begin{array}{l}\text { Further research is needed to design } \\
\text { river floods with sufficient sediments } \\
\text { to stop coastal retreat in the mouth, } \\
\text { but an economic loss can be estimated }\end{array}$ \\
\hline Water quality & $\begin{array}{l}\text { Declining river flows may decrease } \\
\text { water quality (nutrients, chemical } \\
\text { pollutants, salinity, etc.) }\end{array}$ & $\begin{array}{c}\text { Caruso [70] } \\
\text { Zhang et al. [72] }\end{array}$ & $\begin{array}{l}\text { Literature points to ecological and } \\
\text { economic impacts of water quality } \\
\text { decline, but not yet assessed in the } \\
\text { lower Ebro River and delta }\end{array}$ \\
\hline Aquaculture production & $\begin{array}{l}\text { Declining river flows may negatively } \\
\text { affect oyster and mussel production }\end{array}$ & Powell et al. [65] & $\begin{array}{l}\text { Literature points to economic impacts } \\
\text { of river flow decline on aquaculture, } \\
\text { but not yet assessed in the Ebro delta }\end{array}$ \\
\hline Hydropower generation & $\begin{array}{l}\text { Declining river flows negatively affect } \\
\text { hydropower generation }\end{array}$ & Kuriqi et al. [73] & $\begin{array}{l}\text { Literature points to economic impacts, } \\
\text { but not yet quantified in the lower } \\
\text { Ebro River }\end{array}$ \\
\hline
\end{tabular}

\section{Conclusions}

The main impacts deriving from the implementation of the e-flow regime in force established in the Hydrological Plan of the Ebro, from which contrasted scientific and technical information (quantitative or qualitative) is available, are summarized below.

\subsection{Environmental Impacts}

- A mean spring e-flow of $91 \mathrm{~m}^{3} / \mathrm{s}$ would imply a potential useful habitat for the Twaite shad (Alosa fallax) below 20\%, and would not guarantee the reproduction of this fish species of conservation concern.

- The e-flow regime implies a WUA of native species in the lower Ebro River of only $28 \%$, well below the minimum of $50 \%$ required by current Spanish regulations. This would imply a greater proliferation of invasive species and a worsening of ecological quality indices.

- The e-flow regime implies that the salt wedge would be present in the Ebro estuary permanently, and only for 2 months below the island of Gràcia (18 km from the mouth). This would imply a worsening of the ecological conditions of the estuary, as the stratification of water favors the accumulation of organic matter and the decrease of dissolved oxygen (hypoxia).

- With regard to macrophytes, an e-flow regime of sustained low flows without floods would imply a strong proliferation, with a coverage close to $100 \%$ in all areas above $4 \mathrm{~m}$ of depth. This would imply a much stronger proliferation of alien species and blackflies and a decline of native species.

- With regard to sediment transport, the e-flow regime in force does not guarantee the maintenance of spring floods, making impossible in practice the option of transporting sediments to the delta by implementing a sediment by-pass system in the lower Ebro reservoirs. 
- With regard to the protected areas, the habitats and species of the banks and islands of the Ebro will be affected, as permanent low flows and the suppression of floods may change the structure of riparian vegetation and cause its degradation.

\subsection{Socioeconomic Impacts}

- The e-flow regime in force cannot maintain the fishery of the continental marine platform of the Ebro Delta. The link between river flow and fisheries has been studied in the case of anchovies, prawns and mantis shrimps, but more research will be needed to extend them to other species of high commercial interest.

- The available information suggests that the e-flow regime in force would involve a risk of salinization of the rice fields of the Ebro delta, although further studies are needed to quantify the impact.

- The e-flow regime in force will accentuate the sediment deficit and the coastal regression process of the Ebro Delta, which involves a loss of agricultural land and protected natural areas.

- Other socioeconomic activities such as river navigation, tourism, hydropower production or aquaculture will likely be impacted by the e-flow regime in force, although some studies are needed to make a quantitative assessment in socio-economic terms.

The e-flow regime proposed by the Government of Catalonia [19] would be more suitable to maintain the main socioecological functions and values of the lower Ebro River and delta that have been analyzed in the present work. The lower Ebro River and delta is among the case studies where more quantitative and qualitative criteria to set e-flows with a holistic approach have been established. The existing information clearly suggests that the e-flows in force established by the Government of Spain should be increased to guarantee the maintenance of the main socioecological functions and values. However, additional studies are needed to validate the proposal of the Government of Catalonia in some relevant aspects such as the capacity of the river to transport sediments to the delta to avoid coastal regression and mitigate the effects of sea level rise and subsidence, as well as the capacity of floods to controls the spread of macrophytes.

Author Contributions: Conceptualization, C.I. and N.C.; investigation, N.C. and O.B.; writing-original draft preparation, C.I.; writing - review and editing, O.B. All authors have read and agreed to the published version of the manuscript.

Funding: This study was developed within the framework of an agreement between IRTA ("Institut de Recerca i Tecnologia Agroalimentàries") and ACA ("Agència Catalana de l'Aigua"), which acted as financial supporter.

Acknowledgments: The authors acknowledge support from the CERCA Programme/Generalitat de Catalunya.

Conflicts of Interest: The authors declare no conflict of interest. The funders had no role in the design of the study; in the collection, analyses, or interpretation of data; in the writing of the manuscript, or in the decision to publish the results.

\section{References}

1. Poff, N.L.; Zimmerman, J.K.H. Ecological responses to altered flow regimes: A literature review to inform the science and management of environmental flows. Freshw. Biol. 2010, 55, 194-205. [CrossRef]

2. Armitage, P.D.; Petts, G.E. Biotic score and prediction to assess the effects of water abstractions on river macroinvertebrates for conservation purposes. Aquat. Conserv. Mar. Freshw. Ecosyst. 1992, 2, 1-17. [CrossRef]

3. Statzner, B.; Higler, B. Stream hydraulics as a major determinant of benthic invertebrate zonation patterns. Freshw. Biol. 1986, 16, 127-139. [CrossRef]

4. Wood, P.J.; Armitage, P.D.; Cannan, C.E.; Petts, G.E. Instream mesohabitat biodiversity in three groundwater streams under base-flow conditions. Aquat. Conserv. Mar. Freshw. Ecosyst. 1999, 9, 265-278. [CrossRef]

5. Brown, L.R.; Ford, T. Effects of flow on the fish communities of a regulated California river: Implications for managing native fishes. River Res. Appl. 2002, 18, 331-342. [CrossRef] 
6. Arthington, A.H.; Bhaduri, A.; Bunn, S.E.; Jackson, S.E.; Tharme, R.E.; Tickner, D.; Young, B.; Acreman, M.; Baker, N.; Capon, S.; et al. The Brisbane Declaration and Global Action Agenda on Environmental Flows. Front. Environ. Sci. 2018, 6, 45. [CrossRef]

7. Linnansaari, T.; Monk, W.; Baird, D.; Curry, R. Review of approaches and methods to assess Environmental Flows across Canada and internationally. DFO Can. Sci. Advis. Secr. Res. Doc. 2012, 39, 1-74.

8. Tharme, R.E. A global perspective on environmental flow assessment: Emerging trends in the development and application of environmental flow methodologies for rivers. River Res. Appl. 2003, 19, 397-441. [CrossRef]

9. Arthington, A. Comparative Evaluation of Environmental Flow Assessment Techniques: Review of Holistic Methodologies. Land Water Resour. Res. Dev. Corp; Occasional Paper; Land and Water Resources Research and Development Corporation: Canberra, Australia, 1998.

10. Tharme, R.E.; King, J.M. Development of the Building Block Methodology for Instream Flow Assessments, and Supporting Research on the Effects of Different Magnitude Flows on Riverine Ecosystems; Report No. 576/1/98; Water Research Commission: Pretoria, South Africa, 1998.

11. King, J.; Brown, C.; Sabet, H. A scenario-based holistic approach to environmental flow assessments for rivers. River Res. Appl. 2003, 19, 619-639. [CrossRef]

12. Arthington, A.H.; Pusey, B.J. Flow restoration and protection in Australian rivers. River Res. Appl. 2003, 19, 377-395. [CrossRef]

13. Poff, N.L.; Richter, B.D.; Arthington, A.H.; Bunn, S.E.; Naiman, R.J.; Kendy, E.; Acreman, M.; Apse, C.; Bledsoe, B.P.; Freeman, M.C.; et al. The ecological limits of hydrologic alteration (ELOHA): A new framework for developing regional environmental flow standards. Freshw. Biol. 2010, 55, 147-170. [CrossRef]

14. Belmar, O.; Velasco, J.; Martínez-Capel, F.; Peredo-Parada, M.; Snelder, T. Do Environmental Stream Classifications Support Flow Assessments in Mediterranean Basins? Water Resour. Manag. 2012, 26, 3803-3817. [CrossRef]

15. Acreman, M.; Arthington, A.H.; Colloff, M.J.; Couch, C.; Crossman, N.D.; Dyer, F.; Overton, I.; Pollino, C.A.; Stewardson, M.J.; Young, W. Environmental flows for natural, hybrid, and novel riverine ecosystems in a changing world. Front. Ecol. Environ. 2014, 12, 466-473. [CrossRef]

16. Day, J.; Ibáñez, C.; Scarton, F.; Pont, D.; Hensel, P.; Day, J.; Lane, R. Sustainability of Mediterranean Deltaic and Lagoon Wetlands with Sea-Level Rise: The Importance of River Input. Estuaries Coasts 2011, 34, 483-493. [CrossRef]

17. Day, J.W.; Ibáñez, C.; Pont, D.; Scarton, F. Status and Sustainability of Mediterranean Deltas: The Case of the Ebro, Rhône, and Po Deltas and Venice Lagoon. In Coasts and Estuaries; Wolanski, E., Day, J.W., Elliott, M., Ramachandran, R., Eds.; Elsevier: Amsterdam, The Netherlands, 2019; pp. 237-249.

18. Beilfuss, R.; Brown, C. Assessing environmental flow requirements and trade-offs for the Lower Zambezi River and Delta, Mozambique. Int. J. River Basin Manag. 2010, 8, 127-138. [CrossRef]

19. CSTE. Revisió i Actualització de la Proposta de Règim de Cabals Ecològics al Tram Final del Riu Ebre, Delta i Estuari; Departament de Medi Ambient i Habitatge, Generalitat de Catalunya: Barcelona, Spain, 2015.

20. Ibáñez, C.; Prat, N. The environmental impact of the Spanish national hydrological plan on the lower Ebro river and delta. Int. J. Water Resour. Dev. 2003, 19, 485-500. [CrossRef]

21. Ramírez-Hernández, J.; Rodríguez-Burgueño, J.E.; Kendy, E.; Salcedo-Peredia, A.; Lomeli, M.A. Hydrological response to an environmental flood: Pulse flow 2014 on the Colorado River Delta. Ecol. Eng. 2017, 106, 633-644. [CrossRef]

22. Sun, T.; Yang, Z.F.; Cui, B.S. Critical Environmental Flows to Support Integrated Ecological Objectives for the Yellow River Estuary, China. Water Resour. Manag. 2008, 22, 973-989. [CrossRef]

23. Adams, J.B.; Van Niekerk, L. Ten Principles to Determine Environmental Flow Requirements for Temporarily Closed Estuaries. Water 2020, 12, 1944. [CrossRef]

24. Adams, J.B.; Bate, G.C.; Harrison, T.D.; Huizinga, P.; Taljaard, S.; van Niekerk, L.; Plumstead, E.E.; Whitfield, A.K.; Wooldridge, T.H. A method to assess the freshwater inflow requirements of estuaries and application to the Mtata estuary, South Africa. Estuaries 2002, 25, 1382. [CrossRef]

25. Flannery, M.S.; Peebles, E.B.; Montgomery, R.T. A percent-of-flow approach for managing reductions of freshwater inflows from unimpounded rivers to Southwest Florida estuaries. Estuaries 2002, 25, 1318-1332. [CrossRef] 
26. Pelrson, W.L.; Nittim, R.; Chadwick, M.J.; Bishop, K.A.; Horton, P.R. Assessment of changes to saltwater/freshwater habitat from reductions in flow to the Richmond River estuary, Australia. Water Sci. Technol. A J. Int. Assoc. Water Pollut. Res. 2001, 43, 89-97.

27. Richter, B.D.; Mathews, R.; Harrison, D.L.; Wigington, R. Ecologically sustainable water management: Managing river flows for ecological integrity. Ecol. Appl. 2003, 13, 206-224. [CrossRef]

28. Robins, J.B.; Halliday, I.A.; Staunton-Smith, J.; Mayer, D.G.; Sellin, M.J. Freshwater-flow requirements of estuarine fisheries in tropical Australia: A review of the state of knowledge and application of a suggested approach. Mar. Freshw. Res. 2005, 56, 343-360. [CrossRef]

29. Sun, T.; Zhang, H.; Yang, Z.; Yang, W. Environmental flow assessments for transformed estuaries. J. Hydrol. 2015, 520, 75-84. [CrossRef]

30. Davies, P.M.; Naiman, R.J.; Warfe, D.M.; Pettit, N.E.; Arthington, A.H.; Bunn, S.E. Flow-ecology relationships: Closing the loop on effective environmental flows. Mar. Freshw. Res. 2014, 65, 133-141. [CrossRef]

31. Day, J.W.; Maltby, E.; Ibáñez, C. River basin management and delta sustainability: A commentary on the Ebro Delta and the Spanish National Hydrological Plan. Ecol. Eng. 2006, 26, 85-99. [CrossRef]

32. Ibáñez, C.; Pont, D.; Prat, N. Characterization of the Ebre and Rhone estuaries: A basis for defining and classifying salt-wedge estuaries. Limnol. Oceanogr. 1997, 42, 89-101. [CrossRef]

33. Ibáñez, C.; Prat, N.; Canicio, A. Changes in the hydrology and sediment transport produced by large dams on the lower Ebro river and its estuary. Regul. Rivers Res. Manag. 1996, 12, 51-62. [CrossRef]

34. Belmar, O.; Ibáñez, C.; Forner, A.; Caiola, N. The Influence of Flow Regime on Ecological Quality, Bird Diversity, and Shellfish Fisheries in a Lowland Mediterranean River and Its Coastal Area. Water 2019, 11, 918. [CrossRef]

35. European Comission. Ecological FLows in the Implementation of the Water Framework Directive; Guidance Document No. 31; European Comission: Brussels, Belgium, 2015.

36. IRTA. Proposta de Règim de Cabals Ambientals del Tram final del Riu Ebre i Validació Biològica Preliminar; IRTA, Department of Agriculture, Generalitat de Catalunya: Barcelona, Spain, 2008.

37. MARM. Orden ARM/2656/2008, de 10 de Septiembre, por la que se Aprueba la Instrucción de Planificación Hidrológica; Ministerio de Medio Ambiente Rural y. Marino: Madrid, Spain, 2008.

38. CHE. Plan Hidrológico del Ebro 2015-2021; Confederación Hidrográfica del Ebro: Zaragoza, Spain, 2015.

39. Caiola, N.; Ibáñez, C.; Verdú, J.; Munné, A. Effects of flow regulation on the establishment of alien fish species: A community structure approach to biological validation of environmental flows. Ecol. Indic. 2014, 45, 598-604. [CrossRef]

40. Ibáñez, C.; Caiola, N.; Rovira, A.; Real, M. Monitoring the effects of floods on submerged macrophytes in a large river. Sci. Total Environ. 2012, 440, 132-139. [CrossRef] [PubMed]

41. IRTA. Tècniques per a la Gestió del Sediment als Embassaments: Els Cabals D'arrossegament i els Corrents de Densitat; IRTA, Department of Agriculture, Generalitat de Catalunya: Barcelona, Spain, 2009.

42. Sierra, J.P.; Sánchez-Arcilla, A.; Figueras, P.A.; González Del Río, J.; Rassmussen, E.K.; Mösso, C. Effects of discharge reductions on salt wedge dynamics of the Ebro River. River Res. Appl. 2004, 20, 61-77. [CrossRef]

43. Ibàñez, C.; Canicio, A.; Day, J.W.; Curcó, A. Morphologic development, relative sea level rise and sustainable management of water and sediment in the Ebre Delta, Spain. J. Coast. Conserv. 1997, 3, 191-202. [CrossRef]

44. Lloret, J.; Palomar, I.; Salat, J.; Solé, I. Impacto de los Aportes Fluviales sobre la Productividad de la Población de Anchoa del Sur de Cataluña. 2011. Available online: https://digital.csic.es/handle/10261/100871 (accessed on 23 September 2020).

45. Ibáñez, C.; Peñuelas, J. Changing nutrients, changing rivers. Science 2019, 365, 637-638. [CrossRef] [PubMed]

46. Arheimer, B.; Hjerdt, N.; Lindström, G. Artificially Induced Floods to Manage Forest Habitats Under Climate Change. Front. Environ. Sci. 2018, 6. [CrossRef]

47. Staentzel, C.; Beisel, J.-N.; Gallet, S.; Hardion, L.; Barillier, A.; Combroux, I. A multiscale assessment protocol to quantify effects of restoration works on alluvial vegetation communities. Ecol. Indic. 2018, 90, 643-652. [CrossRef]

48. Belmar, O.; Vila-Martínez, N.; Ibáñez, C.; Caiola, N. Linking fish-based biological indicators with hydrological dynamics in a Mediterranean river: Relevance for environmental flow regimes. Ecol. Indic. 2018, 95, 492-501. [CrossRef] 
49. Ibáñez, C.; Alcaraz, C.; Caiola, N.; Rovira, A.; Trobajo, R.; Alonso, M.; Duran, C.; Jiménez, P.J.; Munné, A.; Prat, N. Regime shift from phytoplankton to macrophyte dominance in a large river: Top-down versus bottom-up effects. Sci. Total Environ. 2012, 416, 314-322. [CrossRef]

50. Batalla, R.J.; Gómez, C.M.; Kondolf, G.M. Reservoir-induced hydrological changes in the Ebro River basin (NE Spain). J. Hydrol. 2004, 290, 117-136. [CrossRef]

51. Ibáñez, C.; Alcaraz, C.; Caiola, N.; Prado, P.; Trobajo, R.; Benito, X.; Day, J.W.; Reyes, E.; Syvitski, J.P.M. Basin-scale land use impacts on world deltas: Human vs natural forcings. Glob. Planet. Chang. 2019, 173, 24-32. [CrossRef]

52. Xing, F.; Kettner, A.J.; Ashton, A.; Giosan, L.; Ibáñez, C.; Kaplan, J.O. Fluvial response to climate variations and anthropogenic perturbations for the Ebro River, Spain in the last 4000years. Sci. Total Environ. 2014, 473-474, 20-31. [CrossRef] [PubMed]

53. Rovira, A.; Ibáñez, C.; Martín-Vide, J.P. Suspended sediment load at the lowermost Ebro River (Catalonia, Spain). Quat. Int. 2015, 388, 188-198. [CrossRef]

54. Núñez-González, F.; Rovira, A.; Ibáñez, C. Bed load transport and incipient motion below a large gravel bed river bend. Adv. Water Resour. 2018, 120, 83-97. [CrossRef]

55. Rovira, A.; Ibáñez, C. Sediment management options for the lower Ebro River and its delta. J. Soils Sediments 2007, 7, 285-295. [CrossRef]

56. Genua-Olmedo, A. Modelling Sea Level Rise Impacts and the Management Options for Rice Production: The Ebro Delta as an Example; Universitat Rovira i Virgili: Tortosa, Spain, 2017.

57. Valdemoro, H.I.; Sánchez-Arcilla, A.; Jiménez, J.A. Coastal dynamics and wetlands stability. The Ebro delta case. Hydrobiologia 2007, 577, 17-29. [CrossRef]

58. Kondolf, G.M.; Gao, Y.; Annandale, G.W.; Morris, G.L.; Jiang, E.; Zhang, J.; Cao, Y.; Carling, P.; Fu, K.; Guo, Q.; et al. Sustainable sediment management in reservoirs and regulated rivers: Experiences from five continents. Earth's Future 2014, 2, 256-280. [CrossRef]

59. Guillén, J.; Palanques, A. Sediment dynamics and hydrodynamics in the lower course of a river highly regulated by dams: The Ebro River. Sedimentology 1992, 39, 567-579. [CrossRef]

60. Grimes, C.B. Fishery Production and the Mississippi River Discharge. Fisheries 2001, 26, 17-26. [CrossRef]

61. Lloret, J.; Lleonart, J.; Solé, I.; Fromentin, J.-M. Fluctuations of landings and environmental conditions in the north-western Mediterranean Sea. Fish. Oceanogr. 2001, 10, 33-50. [CrossRef]

62. Daskalov, G. Relating fish recruitment to stock biomass and physical environment in the Black Sea using generalized additive models. Fish. Res. 1999, 41, 1-23. [CrossRef]

63. Lloret, J.; Palomera, I.; Salat, J.; Sole, I. Impact of freshwater input and wind on landings of anchovy (Engraulis encrasicolus) and sardine (Sardina pilchardus) in shelf waters surrounding the Ebre (Ebro) River delta (north-western Mediterranean). Fish. Oceanogr. 2004, 13, 102-110. [CrossRef]

64. San Feliu, J.M. Influencia de los Aportes del río Ebro sobre la Producción Pesquera de la Zona; Dirección General de Pesca Marítima: Gijon, Spain, 1975.

65. Powell, E.N.; Klinck, J.M.; Hofmann, E.E.; McManus, M.A. Influence of Water Allocation and Freshwater Inflow on Oyster Production: A Hydrodynamic-Oyster Population Model for Galveston Bay, Texas, USA. Environ. Manag. 2003, 31, 0100-0121. [CrossRef] [PubMed]

66. COCINT. Estudi de Navegabilitat del Riu Ebre; COCINT: Tortosa, Spain, 2007; p. 30.

67. Genua-Olmedo, A.; Alcaraz, C.; Caiola, N.; Ibáñez, C. Sea level rise impacts on rice production: The Ebro Delta as an example. Sci. Total Environ. 2016, 571, 1200-1210. [CrossRef]

68. Zografos, C. Flows of sediment, flows of insecurity: Climate change adaptation and the social contract in the Ebro Delta, Catalonia. Geoforum 2017, 80, 49-60. [CrossRef]

69. Alizadeh, M.J.; Kavianpour, M.R.; Danesh, M.; Adolf, J.; Shamshirband, S.; Chau, K.-W. Effect of river flow on the quality of estuarine and coastal waters using machine learning models. Eng. Appl. Comput. Fluid Mech. 2018, 12, 810-823. [CrossRef]

70. Caruso, B.S. Regional river flow, water quality, aquatic ecological impacts and recovery from drought. Hydrol. Sci. J. 2001, 46, 677-699. [CrossRef]

71. Duan, W.; He, B.; Chen, Y.; Zou, S.; Wang, Y.; Nover, D.; Chen, W.; Yang, G. Identification of long-term trends and seasonality in high-frequency water quality data from the Yangtze River basin, China. PLoS ONE 2018, 13, e0188889. [CrossRef] 
72. Zhang, Y.; Xia, J.; Liang, T.; Shao, Q. Impact of Water Projects on River Flow Regimes and Water Quality in Huai River Basin. Water Resour. Manag. 2010, 24, 889-908. [CrossRef]

73. Kuriqi, A.; Pinheiro, A.N.; Sordo-Ward, A.; Garrote, L. Flow regime aspects in determining environmental flows and maximising energy production at run-of-river hydropower plants. Appl. Energy 2019, 256, 113980. [CrossRef]

74. Roset, J. Estudi del Comportament del Riu Ebre, en el Tram Móra D’Ebre-Tortosa, per a Analitzar la Navegabilitat en Aquest Tram; Universitat Politècnica de Catalunya: Barcelona, Spain, 2004.

(C) 2020 by the authors. Licensee MDPI, Basel, Switzerland. This article is an open access article distributed under the terms and conditions of the Creative Commons Attribution (CC BY) license (http://creativecommons.org/licenses/by/4.0/). 